\title{
UPAYA MENINGKATKAN BERBICARA ANAK USIA 4-5 MELALUI PENERAPAN METODE BERCERITA PADA ANAK KELOMPOK A TK KRISTEN POMARIMOI DESA TONGUTE SUNGI KEC IBU
}

\author{
Novita Voerman ${ }^{1}$, Nurhamsa Mahmud ${ }^{2}$ \\ ${ }^{1}$ Guru TK Kristen Pomarimoi Halmahera Barat \\ ${ }^{2}$ Dosen Program Studi Pendidikan Anak Usia Dini, Universitas Khairun \\ nnovitavuta@gmaol.com, nurhamsaaca@gmail.com
}

\begin{abstract}
Limitations in the number of vocabulary owned by children can be caused by a lack of simulations given by teachers and parents, as well as the environment, based on the results of initial observation in group A on pomarimoi Christian Early Childhood Education. learning and giving opportunities and freedom of speech in accordance with illustrated stories. Picture story is one medium that enhances ideas, ideas, and feelings, this research is carried out in the rest of class $A$ in early childhood children education in pomarimoi Tomute Sungi village, sub-district of Ibu with the aim of improving speaking skills through hand puppet media, with the number of students with 16 students. The research method used is classroom action research (CAR) which consists of 2 cycles, each cycle consisting of 4 stages namely; 1. Planning, 2. Implementation, 3. Observation, 4. Reflection, data collection techniques used are observation and documentation methods, with data analysis techniques using descriptive percentages, results of research and discussion showing the results of evaluation of group learning in the first cycle of action I 1 4,66 began to develop $(M B)$, and there was an increase in the second action $62 \%$ was developing, and in the results of evaluation of individual learning in action I $31 \%$ began to develop (MB), and $62.50 \%$, then an increase occurred significant in the second cycle, among others, on the eveluation of learning cycle II group action I $75 \%$ and the second action $98.77 \%$, while the results of individual learning on action I cycle II $87.5 \%$ and $98 \%$ in the second action. so that it can be concluded that in order to improve speaking skills using the method of telling stories in early childhood children education in pomarimoi Tomute Sungi villageof Tongute Sungi,sub-district of Ibu can increase optimally.
\end{abstract}

Key words: speaking, story telling

\section{PENDAHULUAN}

Bercerita merupakan kemampuan dasar yang seharusnya diberikan kepada anak usia dini. Oleh karena itu sangat penting metode bercerita dan buku cerita yang menyenangkan dengan tujuan memberikan pembelajaran yang menyenangkan tanpa memberikan beban belajar kepada anak-anak. Semua berjalan sesuai pendidikan usia dini yakni belajar sambil bermain dan bermain sambil 
belajar. Dari hasil observasi awal dengan 16 siswa dengan usia 4-5 tahun terlihat masih kurang berkembang hal ini disebabkan kurangnya peran guru dalam menceritakan buku cerita yakni sebagian besar guru menggunakan metode-metode seperti menulis, berhitung dan bernyanyi, maka menyebabakan bahasa dan berbicara anak masih tergolong rendah. Hal terlihat pada siswa dengan jumlah 16 anak masih terdapat 11 siswa kelancaran dalam berbicara belum lancar atau maksimal, Maka dari hasil observasi awal tersebut maka peneliti merencanakan akan menggunakan metode bercerita. Bercerita merupakan kegiatan berbahasa yang bersifat produktif, dengan bercerita sesorang akan melibatkan pikiran, gagasan, mental dan keberanian sehingga dapat dipahami oleh orang lain, dengan rumusan masalah; Bagaimanakah meningkatkan kemampuan berbicara Anak melalui penerapan metode bercerita? Dengan Tujuan penelitian Untuk mendeskripsikan kmampuan berbahasa anak melalui metode bercerita.manfaat dalam penelitian ini adalah Hasil penelitian diharapakan dapat bermanfaat bagi perkembangan dunia pendidikan.penelitian ini bermanfaat dalam pengembangan literatur.

\section{a. Pengertian Bahasa anak usia dini}

Bahasa adalah sarana komunikasi yang digunakan melalui suatu sistem suara, kata, pola, yang digunakan oleh manusia untuk menyampaikan pertukaran pikiran dan perasaan, bahasa dapat mencakup segala hal komunikasi, baik diutarakan dalam bentuk lisan maupun tulisa, selanjutnya bahasa mempunyai beberapa pengertian menurut, menurut Syamsu (2007: 176) bahasa adalah sarana komunikasi dengan orang lain,

\section{b. Perkembangan Bahasa Anak Usia Dini}

Perkembangan bahasa dipengaruhi oleh lingkungan, menurut Sunarto (2013: 137) bahasa pada dasarnya merupakan hasil belajar dari lingkungan Anak (bayi) belajar bahasa seperti halnya belajar yang lain, meniru dan mengulang hasil yang telah didapatkan merupakan cara belajar bahasa awal

\section{c. Metode Bercerita Pada Anak Usia Dini}

Bercerta adalah cara penyampaian atau penyajian meteri pembelajaran secara lisan dalam bentuk cerita dari guru kepada anak, sejalan dengan hal tersebut menurut Gunarti (2008: 53) bercerita adalah suatu kegitan yang dilakukan seorang untuk menyampaikan suatu pesan, informasi atau sebuah dongen belaka yang bisa 
dilakukan secara lisan atau tertulis, penuturan cerita tersebut dapat dilakukan dengan menggunakan alat peraga atau tanpa alat peraga.

\section{d. Manfaat Metode Bercerita}

Dalam kegiatana pengajaran pada anak usia dini terdapat beberapa manfaat yang dikemukakan oleh Moeslichataoen (2004: 168) tujuan pendidikan TK antara lain:

1. Dapat memberikan sejumlah pengetahuan sosial, nilai - nilai moral dan keagamaan;

2. Kegiatan bercerita memberikan pengalaman belajar untuk berlatih mendengarkan

Anak memperoleh bermacam informasi tentang pengetahuan, nilai dan sikap, untuk dihayati dan diterapakan, dalam kehidupan sehari - hari.

\section{METODE PENELITIAN}

Jenis penelitian ini ialah penelitian penelitian tindakan kelas (PTK), menurut Arikunto, (2006: 3) PTK merupakan suatu pencermatan terhadap kegiatan belajar yang berupa sebuah tindakan yang dimunculkan yang terjadi dalam kelassecara bersama. Tindakan tersebut diberikan oleh guru atau dengan arahan oleh guru yang dilakukan oleh siswa. Selanjutnya Suroso (2007: 30) menjelaskan bahwa PTK didefenisikan sebagai suatu bentuk penelitian yang bersifat feflektif dengan dengan malakukan tindakan-tindakan tertentuagar dapat memperbaiki atau meningkatkan prakti-praktik pembelajaran dikelasnya secara lebih profesional.

Subjek penelitian tindakan kelas ini adalah anak kelompok A TK Kristen Pomarimoi dengan jumlah siswa 20 anak terdiri laki 8 dan perempuan 12 anak, peneliti memilih kelompok A untuk dijadikan sebagai subjek penelitian ini, karena kelompok A merupakan siswa rentang usia paling mudah di (4-5 tahun).selain itu anak kelompok A sebagian besar memiliki kemampuan bercerita masih sangat rendah, dari 20 siswa 16 siswa yang memiliki kempampuan bercerita masih rendah.

Desain penelitian yang digunakan mengacu pada model Kemmis dan Taggart yang terdiri 4 komponen yaituh : perencanaan, pelaksanaan observasi dan tindakan.

Menurut Arikunto (2005: 10) metode pengumpulan data adalah alat bantu yang dipilih dan digunakan oleh peneliti dalam kegiatan pengumpulan data agar 
kegiatan tersebut menjadi sistematis dan dipermudah olehnya, metode pengumpulan data yang digunakan dalam penelitian ini adalah metode observasi dan dokumentasi, metode observasi digunakan yaituh berupa instrumen untuk mencatat perkembangan kemampuan siswa dalam memahami isi cerita dalam penelitian ini instrumen yang digunakan adalah daftar cek list digunakan untuk memastikan kemampuan anak dalam melakukan urutan perbuatan, apakah sudah sesuai dengan prosedur perbuatan yang direncanakan atau sebaliknya

Untuk mengetahui keefektifan kegiatan pembelajaran perlu diadakan analisis data, tehnik analisis data yang digunakan dalam penelitian ini adalah analisis deskriptif kualitatif untuk menganalisa data dengan cara menjelaskan dan menggambarkan hasil penelitian dengan kata-kata atau kalimat yang dipisahkan menurut kategori untuk memperoleh kesimpulan dan untuk mengetahui peningkatan kemampuan siswa dalam memahami cerita, menggunakan rumus yang dijelaskan oleh Anas Sudijono (2011: 43) sebagai berikut:

\section{Persentase $\mathrm{P}=\frac{n}{N} \times 100 \%$}

Keterangan :

$$
\begin{aligned}
& \mathrm{p}=\text { persentasi yang hendak dicari } \\
& \mathrm{n}=\text { jumlah skor yang diperoleh } \\
& \mathrm{N}=\text { jumlah seluruh skor ideal }
\end{aligned}
$$

Perhitungan persentase yang dilakukan dengan cara melihat skor kemampuan total, kemampuan memahami cerita anak yang diperoleh skor kemampuan tertinggi $100 \%$ dan terrendah $0 \%$ kemudian data tersebut diinterprestasikan dalam kategori keuntasan.

\section{PEMBAHASAN}

\section{A. Hasil}

Penelitian ini dilaksanakan di TK Kristen Pomarimoi Desa Tongute Sungi Kec. Ibuyakni terdiri 2 guru dengan jumlah 2 ruangan belajar dan 1 runagan kantor, denagan jumlah siswa kelas A 16 siswa terdiri dari 8 perempuan dan 8 .laki - laki,

Pada evaluasi di siklus I, pertemuan pertama terdapat satu kelompok yakni kelompok 1 yang dapat menceritakan dengan baik $14,66 \%$ sementarag 3 kelompok lainnya atau $86 \%$ masih belum bisa bercerita dan, sementara dilihat dari individu, maka terdapat 3 siswa atau $14,28 \%$ dikategorikan mulai berkembang, 
dengan memperoleh nilai 45 atau 72,47\%, sedangakan 13 siswa lainnya belum bisa sama skali masih dalam kategori Belum berkambang (BB).aktivitas peneliti dan siswa pada siklus I tindakan II ini ternyata dalam pembelajaran masih perlu perbaikan hal ini terlihat pada hasil observasi baru terdapat 5 siswa, memperoleh nilai 65 atau $68,75 \%$ sementara 11 lainnya masih kategori belum berkembang (BMK) dikategorikan belum berbicerita atau berbicara dengan jelas sementara pada kelompok mmperoleh nilai yaitu kelompok 1, memperoleh nilai 50 atau 62,5\% dan 3 kelompok lainnya dengan mengalami peningkatan.

Selanjutnya pada siklu II Pada siklus II pertemuan pertama ini, sudah mulai menunjukan peningkatan, hal ini terlihat dari hasil observasi dan hasil refleksi pertemuan pertama pada siklus II yaitu terdapat $62,5 \%$ atau 10 siswa dari 16 siswa yang mengalami kemajuan dengan memeroleh nilai 70 atau $87,5 \%$, dan dilihat dari aktivitas kelompok 4 memperoleh nilai 60 atau 55,55\%, sementara dilihat dari penningkatan kelompok terjadi peningkatan yakni kelompok 1,kelompok 2 , dan kelompok 3, memperoleh nilai $6075 \%$ dan kelompok 4 memperoleh nilai 50 $62 \%$.

Pada siklus II pertemuan kedua ini, sudah mulai menunjukan peningkatan, hal ini terlihat dari hasil observasi dan hasil refleksi pertemuan kedua pada siklus II yaitu terdapat $87,5 \%$ atau 14 siswa dari 16 siswa yang mengalami kemajuan dengan memeroleh nilai 80 atau $98,77 \%$, dan 2 siswa $12,5 \%$ memperoleh nilai 60 atau 55,55\%, sedangkkan penilaian pada kelompok sudah mengalamai peningkatan yang signifikan, hal ini terlihat pada kelompok 1 memperoleh nilai 80, kelompok 2 memperoleh nilai 80, dan kelompok 3 dan kelompok 4 memperoleh nilai 70.

\section{B. Pembahasan}

Berdasarkan proses pembelajan dengan kemampuan berbicara, terdapat beberapa siklus yang dilalui pada penelitian ini, yaitu:

Pada siklus I, menunjukan hasil yang dibahas sebagai berikut:

1. siklus I tindakan pertama dengan menggunakan metode bercerita pada aktivitas pembelajaran kelompok yang belum berkembang atau belum mengalami peningkatan $86 \% \mathrm{BB}$, sementara yang kategori mulai berkembang $14,66 \%$ (MB), sementara dilihat dari aktivitas pembelajaran individu pada siklus I tindakan I mulai berkembang $31 \%$, dan 69\% BM, atau belum mengalami perkembangan;

2. Pada pertemuan kedua siklus I terjadi peningkatan yakni pada aktivitas hasil pembelajaran kelompok $62 \%$ sedang berkembang menjadi, dan pada hasil evaluasi pembelajaran individu $31 \%$ mulai berkembang, dan $69 \%$ belum berkembang. 
Selanjutnya pada siklus II, menunjukan hasil yang dibahas sebagai berikut:

1. Berdasarkan proses pembelajaran dengan menggunakan metode bercerita dengan meningkatkan kemampuan berbicara mengalami penigkatan padahal ini terlihat pada hasil evaluasi pembelajaran pada siklus II tindakan I pada aktivitas pembelajaran individu 62\%,50\% sedang berkembang, dan 37,50\% mulai berkembang, sementara padaaktivitas pembelajaran kelompok $75 \%$ sedang berkembang dan 62,50\% mulai berkembang; dan

2. Pada pertemuan ke 2 siklu II terjadi peningkatan yang signifikan yaitu pada aktivitas pembelajaran individu mencapai $87 \%$ dikategorikan sudah berkembang, dan yang belum berkembang $12,50 \%$, sementara hasil evaluasi pembelajaran kelompok $98,77 \%$ yang dikategorikan sudah berkembang dan $87 \%$ dikategorikan sedang berkembang.

\section{SIMPULAN}

Berdasarkan hasil analisis data pada peelitian ini, maka terdapat beberapa simpulan yang dibuat oleh peneliti sebagai berikut: (1) Proses penilaian pada pembelajaran dengan menggunakan metode bercerita pada evaluasi pembelajaran kelompok, pada siklus I pertemuan pertama $86 \%$ belum berkembang (BB), sementara pada hasil pembelajaran individu $69 \%$ yang belum berkembang dan $31 \%$ Mulai berkembang (MB), kemudian pada tindakan ke II pada siklus I pada hasil pembelajaran kelompok $62 \%$ sedang berkembang dan $38 \%$ belum berkembang (BM); (2) Pada hasil pembelajaran dengan menggunakanmetode bercerita untuk meningkatkan kemampuan berbicara pada siklus II tindakan I, hasil eveluasi pembelajaran kelompok $75 \%$ sedang berkembang (SB), dan 62,50 mulai berkembang (MB), dan pada hasil pembelajaran individu $75 \%$ sedang berkembang (SB), 62,50\% mulai berkembang (MB) selanjutnya mengalami signifikan pada tindakan ke II siklus II yakni pada hasil evaluasi pembelajaran individu mencapai $87 \%$ sedang berkembang, dan $12,50 \%$ belum berkembang (BB), sementara pada evalusi pembelajaran kelompok mengalami peningkatan mencapai 98,77\% dikategorikan sudah tuntas dan $87,50 \%$ sedang tuntas.

\section{DAFTAR PUSTAKA}

Arikunto, S. 2002. Prosedur Penelitian. Jakarta. Rineka Cipta.

Anas, S. 2011. Pengantar Statistik Pendidikan. Jakarta: Rajawali Press. 
Bactiar, S. Bachir. 2005. Perkembangan Anak Usia Dini. Jakarta. Cahaya Mulya Press.

Departemen Pendidikan Indonesia, Kurikulum Pendidikan, tahun 2010.

Peraturan Mentri Pendidikan Nasional Nomor 58 tahun 2009, Standar Pendidikan Anak Usia Dini, Jakarta, Direktoral Jendral Pembinaan TK dan SD 2014.

H. Sunarto. 2013. Perkembangan Peserta Didik. Jakarta. PT. Rineka Cipta.

Syamsu,Yusuf. 2007. Psikologi Perkembangan Anak dan Remaja, Bandung : PT Reaja Rosdakarya.

Sari, A. 2010. Upaya dalam Menumbuhka Kemampuan Bahasa Anak-Anak Surabaya. Bina Karya. 